\title{
IS THE GERMAN QUALIFICATIONS FRAMEWORK AN INSTRUMENT THAT CONTRIBUTES TO PERMEABILITY AND PROGRESSION WITHIN THE VET SYSTEM? - AN INTERNATIONAL PERSPECTIVE
}

\section{INTRODUCTION}

The European Qualifications Framework (EQF) can be seen as a starting point from which the various vocational education and training (VET) systems in Europe are challenged to establish their respective National Qualifications Frameworks (NQFs), complying with the so-called Lisbon-Copenhagen-Maastricht Process (Dunkel \& Jones, 2006). One implication is the political objective to open up education and VET systems in the context of concepts such as the "learning economy" or "lifelong learning". One of the key-stones of the "European Union (...) lifelong learning agenda" hereby is the concept of "Competence-based Training" (CBT), which emphasizes that competences can be developed in various ways, "irrespective of the routes of acquisition" (Westerhuis, 2011, p. 68), i.e. learning outcomes should be independent of the context in which learning takes place (Misko, 1999). Another facet is sorting existing qualifications along (competence) dimensions and levels which are based on general descriptors. VET systems with a strong focus on initial training obviously face the most serious challenges here. The "nation-specific" strategy of Germany is to link two worlds; keeping the well functioning elements of the VET system (such as the dual system of apprenticeship training) stable while at the same time trying to cope with the prominent "European issues" such as "informal learning", "modularization" and "accreditation of prior learning". Another issue is the transition from VET to higher education which is seen as an integral element of a more "open" educational architecture, while hitherto sub-systems in Germany (above all the school system and VET) have been working as traditionally clearly segregated entities with hardly any competence-relevant links between each other.

With respect to VET provision in a given country, there is a historical character of the VET system which determines its structures and function, including its links to the labor market. This means that the general significance given to apprenticeship as one specific institutional and didactical solution to the problem of skill formation can differ, mostly depending on the availability of alternative or socially preferred pathways and qualifications. Besides the apprenticeship system, school-based forms of vocational learning, such as vocational colleges (e.g. in the federal state 
of Baden-Württemberg, cf. Deissinger, Smith \& Pickersgill, 2006) represent more or less traditional courses and qualifications which are normally institution-based, shaped by state influence, providing underpinning knowledge for work-based training, but they can also function as purely theoretical alternatives to workplace learning. Experiences with these school-based sub-systems stretch from highly labormarket relevant training provision (e.g. in Austria, cf. Aff, 2006) to more or less ambivalent functions of vocational schools (e.g. in France, cf. Ott \& Deissinger, 2010).

An important overarching issue, besides institutionalization, seems to be the social and economic understanding of various vocational pathways (Harris \& Deissinger, 2003), but also the evaluation given to VET in general, which becomes clearly manifest when we look at the challenges imposed by the European Qualifications Framework. It is understood that countries which differ in terms of their VET systems and underlying traditions, especially with respect to the relationship between full-time VET and company-based training, also differ in terms of their capacity to adapt to the European VET policy agenda, above all when it comes to National Qualifications Frameworks (Young, 2003).

Germany's NQF (Deutscher Qualifikationsrahmen or DQR), under development for five years now (Deissinger, 2009; Esser, 2012), requires a re-definition of borders, pathways, levels and transition options between (a) VET and other educational sub-systems, but also (b) between sub-systems within the VET architecture, such as full-time VET, vocational preparation or foundation courses, or further training. This paper focuses on open issues and obvious areas of tension associated with the EQF/ NQF paradigm, and picks up those limitations of the German VET system which are responsible for profound differences between the German learning culture, which is basically an "apprenticeship culture", and the English case. Tensions arise if this means not just to comply with European concepts in a formal way, but when it comes to questioning established structures which are barriers - also from a national perspective - for progression and permeability within the education system.

\section{THE ENGLISH "BLUEPRINT": THE DIFFICULTY OF ESTABLISHING QUALITY IN THE FACE OF A NATIONAL QUALIFICATIONS FRAMEWORK}

It is generally understood that the European framework concept has its roots in what happened in England (and the UK in general) in the area of VET policy in the 1980s and, at the same time, in a specific understanding of "competence" typical of the Anglo-American or Anglo-Saxon approach, which consists in the (behavioristic) conviction that learning should be focused on "someone's ability to perform, rather than demonstrating the possession of knowledge" (Westerhuis, 2011, p. 77). The outcomes-based approach to qualifications obviously lies behind "English innovations" such as NVQs (National Vocational Qualifications) and modularization (Brockmann, Clarke \& Winch, 2010, p. 91). Hereby, work-based learning "should be confined to the immediate requirements of acquiring the skills associated with 
a particular job or task" - with the implication that learning beyond this scope is not just "regarded as superfluous, but a positive hindrance to effective working" (ibid., p. 92).

One of the crucial characteristic features of VET in England, which appears to be a perfect breeding ground for these ideas, is that "learning on the job is often the only way to acquire skills, unlike in other countries with comprehensive and intense programmes of initial skill formation covering almost all new entrants into the industry and taking place in colleges and workshops and on sites" (Clarke \& Winch, 2006, p. 78). Correspondingly, England has become the protagonist of the "framework concept", establishing a National Qualifications Framework as early as in the late 1980s (Jessup, 1991). However, the general political motives which Keating describes as supporting "strong and accessible qualifications pathways, a transparent qualifications system, and one that facilitates lifelong learning" (Keating, 2008, p. 1), were not the only underlying convictions when the country, in 1986, introduced NVQs for work-based learning. The main purpose was to offer "a means of obtaining credit for work-based activities" by providing "a structure for the work placement which culminates in a portfolio of evidence" (Morgan, 1997, p. 186). At the same time, in Wolf's words, NVQs were designed to "cover a particular area of work, at a specific level of achievement". "Competence" hereby was "based on the fundamental assumption that, for each industry, there exists a single identifiable model of what 'competent' performance entails. The idea that, for each role, there exists such an agreed notion of competence, which can be elicited and command consensus, is fundamental to any assessment system of this type" (Wolf, 1998, p. 210). Therefore, one of the central ideas of the English framework approach is the combination of "levels", "competence dimensions" and "qualifications".

Although the English apprenticeship system "arose out of the need to stimulate the supply of intermediate-level skills in the economy in the 1990s" and clearly was "the mainstream successor to a range of Government-funded training schemes" (Hogarth, Gambin \& Hasluck, 2012, p. 52; cf. Deissinger \& Greuling, 1994), its present structure also contains elements which point to "progression routes" and permeability between VET and higher education. The idea of an NQF came up in the 1990s, as a follow-up development to NVQs in the late 1980s (Young, 2003). Its purpose has been to act as an umbrella for school-based, vocational and academic qualifications, as well as providing pathways for progression in the education system (at least in theory) through to postgraduate and doctoral studies. Whereas Germany still operates with a one-standard notion of apprenticeship (due to training duration of mostly three years), in England apprenticeships are not confined to initial training, but can be delivered on three levels, including a kind of "pre-stage" or "sub-academic" variant leading into the higher education sector (cf. www.apprenticeships. org.uk). The programme distinguishes between Intermediate Level Apprenticeships, Advanced Level Apprenticeships and Higher Apprenticeships, on levels two, three and four respectively. Apprentices work towards qualifications that are located in the Qualifications and Credit Framework (QCF), e.g. a Professional Diploma, with this 
framework corresponding with the Framework for Higher Education Qualifications (FHEQ). These frameworks may be called spin-off products of the NQF. However, not all apprenticeships lead, through a Higher Apprenticeship, into the degree section of the NQF, which offers "Foundation Degrees" as a pre-stage to undergraduate studies.

Leveling initial training within the NQF means that boundaries between various sectors of the educational and/or training system, including higher and further education, are no longer defined as culturally determined entities with demarcations and functional specifities, but are more and more considered as permeable sub-systems of one system which bears the functional label of "lifelong learning". This statement should not, however, ignore the massive quality problems within the English VET system and the problem of reputation and social acceptance in relation to academic qualifications that are more portable on the labor market than vocational ones (Bynner, 2011, p. 20).

As already mentioned, lifelong learning with the framework concept relies on a specific understanding of "competence" but also requires "open" training markets without strong formal regulation (Harris, 2001). The idea of a flexible, individual and ongoing acquisition of competences which should be independent from institutions, courses and curricula also provides the basis for a new understanding of learning and assessment (Wolf, 1998), such as recognition of prior learning (RPL) or accreditation of prior experiential learning (APEL).

It is interesting, though, that the problems for VET in England lie, in the first place, not only in this characterization of the reference point of learning being "ready-tohand tasks in the workplace" (Brockmann et al., 2010, p. 92), but in the heterogeneous character and quality of vocational education as such, with the apprenticeship system clearly being one of the weakest elements. Terminology problems occur with the various meanings of sub-types of VET, mixing "apprenticeship", "vocational education" and "training", with a clear tendency to define anything belonging to the vocational sphere in a narrow, "non-expansive" sense, once again indicating a specific understanding of competence which corresponds with the importance of this concept, originally emerging in the sphere of vocational training, in the international debate. Brockmann, Clarke and Winch report this when they mention the historical heritage of a traditional combination of workplace learning with some form of off-the-job instruction and theoretical knowledge relevant to the respective occupation or field of activity which "never succeeded in establishing themselves as major alternative routes from school to work", let alone in standing for "sufficient prestige to gain widespread confidence and recognition from the government, parents, young people, trade unions and employers" (ibid.; cf. Winch \& Hyland, 2007). What is typical for the English "vocational patient" against this background, and also a manifestation of a cultural past that did not allow VET in general to become the focus of employers and the state alike (in contrast with the German counterpart), is the fact that all the programs, initiatives and terminological inventions from the 1970s onwards failed to lead to substantial changes in the perception of VET as such, or 
to substantial changes in the system. Major researchers in the UK (Unwin, 1999; Ryan, 2001; Bynner, 2011; Fuller \& Unwin, 2011) pick up these issues constantly by pointing, above all, to the pedagogical deficits of the English approach which results from discounting the importance of educational elements in VET programs on the one side, and from sticking to a strict terminological divide between "education" and "training" on the other. There seems to be an obvious paradox in that a country with a poor reputation for vocational education comes up with a conceptual innovation such as a National Vocational Qualifications Framework, which the government commanded to be installed when dissatisfaction with VET continued to persist in the 1980s.

Another trait of English VET, which leads us to question whether this is really a pure "market model" of skill formation (Greinert, 1988), is that there is a strong school-based route into employment. This route, due to distrust of company-based training and lack of commitment from employers, holds the advantage that VET provision is more comprehensive and theory-based, i.e. more occupational than most training leading to NVQs, but is considered to have "limited scope for employment" (Brockmann et al., 2010, p. 93). This means that we encounter "two worlds" in the English VET system due to a widening gap between school-based and work-based pathways (ibid.) as one expression of institutional demarcation lines between (general or general vocational) academic and vocational education in England.

The contrast between the Anglo-Saxon approach to VET and the German one has, for a number of decades, been a topic of VET research in England, and the UK in general, including the critical link between economic performance and skill formation (Prais, 1981; Raggatt, 1988), but also quality issues. Ryan (2001, p. 137) brings into focus, looking at apprenticeships in particular, the "absence of process regulation" in the English case due to a "competence-based" approach to skill certification. He concludes that "(...) what matters in principle for NVQ certification is demonstrated competence in the performance of work tasks, and that alone. Educational attainments should indeed form part of that assessment if they are needed for competence, but are otherwise to be discarded as superfluous (...)". Therefore, it may be stated that in England the traditional neglect of formal work-based learning has even been exacerbated by $\mathrm{CBT}$ and modularization.

\section{GERMANY'S EUROPEAN STARTING POSITION: SPECIFIC PROBLEMS DERIVING FROM AN APPRENTICESHIP-BASED VET SYSTEM}

Germany is a country with a strong focus on educational principles and process regulation, including in VET, due to particular historical developments and a specific cultural and pedagogical pattern which supports an esteem for practical learning (Deissinger, 2004). Since the apprenticeship system (dual system) is the strongest stream in post-compulsory secondary education in Germany, its institutionalization and didactical systematization and standardization are typical of the German learning culture in VET (Harris \& Deissinger, 2003). In this system, with 
its 350 recognized training occupations, the commitment and interest of chambers (as crucial employer organisations), trade unions and companies are essential and are considered as prerequisites for keeping it going. A specific pedagogical component exists in the compulsory subjects provided through school attendance in the part-time vocational school, which stands both for theoretical vocational learning as well as general education during the apprenticeship. Ryan puts this in contrast with the British approach to VET: "A striking difference from Germany is the absence of minimum training periods, such as a three-year programme for bakers. Similarly, apprentices need not take part-time technical education." (Ryan, 2001, p. 136). This compulsory post-secondary apprenticeship system in Germany is lawbased, not only through the education legislation of the federal states, but also with respect to company-based training - through a national workplace training law, the Vocational Training Act (VTA), which can be characterized by two features (Deissinger, 1996):

- It places vocational training in the hands of firms and chambers and thus emphasizes the principle of self-government. The VTA takes account of the traditional features of guild apprenticeship while at the same time submitting in-company training to homogeneous, supervisable and examinable standards. The "competent authorities" function as monitoring agencies for incompany training and organize and certify exams during and at the end of an apprenticeship.

- Although it only covers company-based training, the VTA contains stipulations which confirm and refer to the existence of the second "learning venue", the parttime vocational schools. The legal framework is based on the discrete legislative functions of states and the federal level under the German Constitution. Against this background, vocational training is linked up both with the law on schools and the law on labor.

With the political idea in mind of having to transfer the EQF philosophy, at least formally, to a national semantic level, the specific German tradition and use of "Kompetenz" appears "holistic" rather than "functional", and therefore is more related to the French or Dutch understanding of competence (Westerhuis, 2011). For Germany, this poses the challenge of establishing a "competence matrix" featuring vertical differentiation in reference levels and horizontal differentiation with respect to various competence dimensions across traditionally separated spheres within the education system without ignoring the specific quality of its established pathways into employment. Leaning towards the EQF definition of knowledge, skills, and competences as the relevant dimensions of "competence" in general, the German framework (DQR) has now devised four competence dimensions (technical competence, methodical competence, social competence, personal competence). This classification clearly has its roots in the concept of Berufliche Handlungskompetenz (vocational action competence). However, other qualifications (certificates) also have to be included within the drafted DQR matrix. This means that qualifications 
(which are normally strongly input-steered as they are based on time, curricula, examination modes etc.) have to be translated into notions of competence in line with the levels of the DQR.

In Germany, the term "competence" is mainly used in combination with vocational initial training in the dual system. Berufliche Handlungskompetenz hereby stands for the objective that apprentices should attain the capacity for self-regulation and problem-solving in a broad context of occupational tasks, for which they are trained in a systematic way both in the company and in school, with the latter providing general education and underpinning vocational knowledge (Kultusministerkonferenz, 2007). The drafted DQR quite clearly arrives at a typical notion of competence which underlies this philosophy of VET in the dual system of apprenticeship training in Germany. This understanding of competence has always been linked to inputs rather than outcomes, because occupational competence as a result of training "embodies all that is associated with an occupational identity" (Winterton, 2009, p. 686). Beyond technical issues, there is no doubt that the process of establishing a consensus-based DQR ultimately requires a common understanding and a common will of stakeholders to materialize this understanding of competence in the various fields of education and training, but also to tackle the "construction sites" of the German VET system. This means that structural tasks directly affecting the DQR are just one element on the "European pathway" which needs to be taken. Germany is also facing the issue of legal, administrative and political consequences arising from the competence concept and its national realization.

The strong focus on initial training in the dual system has constantly provoked criticism within the national VET debate, quite in contrast with the above-mentioned international reputation of this model of skill formation. Against the background of missing links between various forms and sub-systems of VET, the federal government in 2005 realized a revision of the VTA referring to the following intentions (BMBF, 2005):

- the inclusion of vocational preparation schemes within the scope of regulation of the law and with it the implementation of an appropriate system of qualification modules;

- the transferability of credits obtained in school-based VET via by-laws of the federal states;

- a more intense internationalization of VET by providing opportunities for apprentices to undergo part of their vocational training abroad; and

- an ongoing modernization of examinations by establishing the "extended" final examination.

It is obvious that modernization within the dual system currently mainly takes place on the curricular level. It has materialized in the creation or revision of training schemes within the system of "skilled training occupations" which now even include tentative features of modularization. However, there is a general conviction in the 
research community that the system has to become even more flexible with respect to the "transition system" (Euler \& Severing, 2006; Baethge, Solga \& Wieck, 2007). On the other hand, interest groups, such as trade unions and chambers, are eager to underline their belief in the efficiency of the dual system as the "silver bullet" when it comes to integration in skilled employment.

As an instrument for "internal modernization", the new VTA passed in 2005 contains comparatively innovative stipulations which concern the relationship between apprenticeship training in a recognized occupation and full-time VET courses leading to vocational qualifications (Lorenz, Ebert \& Krüger, 2005):

- The federal states can now determine which courses in full-time vocational schools or in comparable institutions shall lead to a partial accreditation in a subsequent apprenticeship. Applications for accreditation have to be submitted individually to the appropriate chambers (as the "competent bodies").

- Learners graduating from a full-time course leading to a vocational qualification shall get the permission to undergo a final examination in a recognized occupation before the regional chamber if the occupational profile proves to be equivalent. This regulation also includes so-called "school occupations" outside the scope of the VTA or the Craft Regulation Act.

Therefore, on paper at least, there is a situation in Germany where formal preconditions exist through which a tentative approach towards more harmonization in the VET system could be undertaken. However, the situation of full-time VET in Germany shows that, in an "apprenticeship country", alternative pathways leading to vocational qualifications are hard to establish as more or less equivalent - which, as we have seen, is a major conceptual idea underlying the EQF and its national siblings.

\section{FULL-TIME VET IN GERMANY: SERVING TWO MASTERS}

German school-leavers not going to university normally undertake apprenticeships in the dual system. In the past decades, the dual system has been faced with challenges associated with assimilating East Germany and with the critical training market situation that emerged in the 1990s. One result has been the so-called "transition system" (Krewerth \& Ulrich, 2006; Neß, 2007), which has established itself as a "catch-basin" for disadvantaged young people, most of them weaker learners or migrants. Special training programs and vocational preparation schemes offered in full-time VET are now counted as what may be called an ancillary system to the dual system.

Alternative pathways and opportunities for young people outside the dual system bear the weakness of being too far away from real working life. This is even the case for workplace-related learning arrangements, such as practice firms in the so-called "vocational colleges" (Berufskollegs). This type of vocational school is an example of VET outside the dual system and illustrates the problems inherent in full-time 
VET in Germany. Normally the students are aged between 16 and 18, and they have to hold a medium-level school-leaving qualification. The function of vocational colleges is to provide young people with an "assistant qualification", and the attainment of an entry qualification for universities of applied sciences (Fachhochschulen). Basically, these schools offer hybrid qualifications - which in fact correspond with one of the basic ideas of the framework concept, i.e. improving progression from VET to higher education.

While the official function of this type of school is supposed to be a combination of training and educational progression, empirical findings (Deissinger \& Ruf, 2006; Deissinger, 2007) show that

- the occupational qualification is generally not valued as useful or attractive - a result which is supported by the fact that most students report their intention to take up an apprenticeship after completion of the Berufskolleg;

- the parking function of this kind of school seems to be very strong in the first year of the course, while students in their second year have a clearer understanding of their goals and motivations - which predominantly means taking up an apprenticeship after completion, or progression to higher education;

- the Berufskolleg seems to function as a bridge between school education and the dual system and therefore cannot be regarded as a real substitute or alternative in relation to the apprenticeship system.

This specific type of school now provides the entrance qualification for the Fachhochschulen as the regular qualification that can be obtained after two to three years. Under certain conditions, according to the Baden-Württemberg education law, an assistant qualification can be obtained, which means that the "hybridity" is now less important than in the past. On the other hand, it cannot be asserted that links to the dual system would compensate for this, let alone in the sense of a reliable system of "accreditation of prior learning", while the most important motivation for students seems to be the improvement of their position in the training market for a subsequent apprenticeship (e.g. banking or insurance) due to the insight that a college-based course fails to offer portable labor-market relevant occupational qualifications (Deissinger \& Ruf, 2006, pp. 168f.).

Although it is still too early to assess the consequences of the new stipulations of the (revised) VTA, potentially they could help to establish bridges between separated sub-systems and hence comply with some of the EQF premises. However, there is no doubt that their practical relevance is dependent on the value companies and chambers place on full-time VET in general and also on the political will of governments to arrange what in Anglo-Saxon countries is called "recognition" or "accreditation" of prior learning (including formal and informal learning). It is obvious that while the dual system still has no substantial links with higher education, vocational full-time schools can indeed partly build these bridges, but - in contrast to Austria (Aff, 2006) - they have to fulfill more or less ambivalent functions in relation to the labor market. 


\section{CONCLUSION: WHERE IS THE GERMAN QUALIFICATIONS FRAMEWORK LIKELY TO LEAD US?}

Against this background "European construction sites" for Germany remain, although they have to be solved primarily from a national point of view, i.e. in the German case, with a clear focus on the so-called "transition system" and the specific problems of full-time VET:

- Links between different streams within the VET architecture still seem nonexistent and they are normally highly dependent on federal state or regional regulations, especially when it comes to vocational preparation and integration measures.

- Differentiation within VET is weak in terms of skill levels and duration, although, with a view to disadvantaged young people training in the dual system, for pedagogical reasons, this should not be addressed exclusively to the stronger learners.

- Links between non-formal and informal learning and formal VET are virtually non-existent. It is interesting that even in the French education system concepts have been implemented which correspond to the premises of the EQF (Ott \& Deissinger, 2010).

- Full-time VET remains detached from the dual system and may be seen as the clearly weaker sub-system when it comes to portable qualifications relevant for employment.

The first step "into Europe" for the German VET system could be to re-assess and re-develop its system of links and accreditation mechanisms, not only with respect to full-time VET. Such a move would not necessarily require it to copy the English system but would reflect the acknowledgement of one of the crucial premises underlying the EQF, i.e. the appeal to "build bridges" between sub-systems, pathways, forms of learning and institutions in the VET system.

In the German political and scientific debate, national agencies such as the Federal Institute for Vocational Education and Training (BiBB) "welcome the development of a European Qualifications Framework in principle", as the Deputy President of this national agency has phrased it (Weiss, 2007), stating that attainability of any level of qualifications should become possible via the "vocational pathway". On the other hand, initial training is still seen as fundamental in this process. This does not mean that there is a serious ambition to question the vocational principle with its holistic notion of "full" and "fundamental" qualifications depicted in the term Berufliche Handlungskompetenz, or the strong regulatory context in which the dual system operates. While the French and English VET policies - regardless of their specific national problems as "low status" VET countries - appear to be much more pragmatic, the German debate can be characterized as considerably protective and conservative, with the trade unions and the craft sector as the major defenders of the traditional institutional arrangements in the VET system (e.g. Drexel, 2005). A first 
major mental shift could be to acknowledge that the German VET architecture no longer is as clearly dominated by the dual system as it was in the past.

In January 2012, the relevant stakeholders in Germany (federal states, the federal ministry of education and science, social partners), who are represented in the Working Group dealing with the German Qualifications Framework, agreed on a draft which proposes a preliminary clarification of levels and qualifications (Esser, 2012). According to this resolution, normal (three- and three-and-a-half-year) dualsystem qualifications will be defined on level 4 , occupational qualifications from shorter courses on level 3 , and the master craftsman (quite astonishing) will be set at level 6 (which corresponds with a bachelor degree). It seems even more remarkable that there has been no agreement on the equivalence of general school qualifications and vocational qualifications so far - with the weird result that the former ones have been, for the time being at least, excluded from the proposal. This shows that the DQR will remain a construction site for some time to come. It is also evident from this current stage of the debate that dealing with the framework concept remains focused on input factors, such as course duration or curricular distinctiveness, but is also strongly associated with stakeholder interests and perceived quality differences between courses. All this underlines the statement by Winch, who concludes that the "changing of a VET system, just like the changing of an education system more generally, is dependent upon and also has ramifications throughout society and politics. It cannot be a simple matter of a technical recipe to aid economic growth, but touches on the heart of what any society is about." (Winch, 1998, p. 377).

\section{REFERENCES}

Aff, J. (2006). Berufliche Bildung in Vollzeitschulen - konjunkturabhängige Hebamme des dualen Systems oder eigenstăndige bildungspolitische Option? In M. Eckert, \& A. Zoller (Eds.) Der europäische Berufsbildungsraum - Beiträge der Berufsbildungsforschung. Bielefeld: Bertelsmann, 125-138.

Baethge, M., Solga, H., \& Wieck, M. (2007). Berufsbildung im Umbruch. Signale eines überfälligen Aufbruchs. Berlin: Friedrich-Ebert-Stiftung.

Brockmann, M., Clarke, L., \& Winch, C. (2010). The Distinct Nature of Work-based VET in England: a reflection of employer interests? In F. Rauner, \& E. Smith (Eds.) Rediscovering Apprenticeship. Dordrecht: Springer, 91-102.

Bundesministerium für Bildung und Forschung, BMBF (2005). Die Reform der beruflichen Bildung Berufsbildungsgesetz 2005. Bonn: BMBF.

Bynner, J. (2011). Youth Transitions and Apprenticeships: a broader view of skill. In T. Dolphin, \& T. Lanning (Eds.) Rethinking Apprenticeships. London: IPPR, 17-28.

Clarke, L., \& Winch, C. (2006). Vocational Education: conceptual differences between Britain and Germany. In J. J. Beichel, \& K. Fees (Eds.) Bildung oder outcome? Leitideen der standardisierten Schule im Diskurs. Herbolzheim: Centaurus, 75-90.

Deissinger, T. (1996). Germany's Vocational Training Act: Its Function as an Instrument of Quality Control within a Tradition-based Vocational Training System. Oxford Review of Education, 22(3), 317-336.

Deissinger, T. (2004). Apprenticeship Cultures - a comparative view. In S. Roodhouse, \& D. Hemsworth (Eds.) Apprenticeship: An Historical Re-invention for a Post Industrial World. Bolton: University Vocational Awards Council, 43-58. 
Deissinger, T. (2007). „Making Schools Practical”: Practice firms and their function in the full-time vocational school system in Germany. Education and Training, 49(5), 364-379.

Deissinger, T. (2009). Der Deutsche Qualifikationsrahmen - Chance zur Lơsung nationaler Problemlagen. Berufsbildung in Wissenschaft und Praxis, 38(6), 40-43.

Deissinger, T., \& Greuling, O. (1994). Die englische Berufsbildungspolitik der achtziger Jahre im Zeichen der Krise eines „Ausbildungssystems“: Historische Hintergründe und aktuelle Problemlagen. Zeitschrift für Berufs- und Wirtschaftspädagogik, 90, 127-146.

Deissinger, T., \& Ruf, M. (2006). Übungsfirmen am Kaufmännischen Berufskolleg in BadenWürttemberg. Praxisorientierte vollzeitschulische Berufsausbildung zwischen Anspruch und Wirklichkeit. Paderborn: Eusl.

Deissinger, T.,'Smith, E., \& Pickersgill, R. (2006). Models of Full-time and Part-time Vocational Training for School-leavers: A comparison between Germany and Australia. International Journal of Training Research, 4(1), 30-50.

Drexel, I. (2005). Das Duale System und Europa. Ein Gutachten im Auftrag von VER.DI und IG-Metall. Bonn.

Dunkel, T, \& Jones, S. (2006). Lissabon - Kopenhagen - Maastricht: Europäisierung nationaler Berufsbildung. In U. Clement, I. Le Mouillour, \& M. Walter (Eds.) Standardisierung und Zertifizierung beruflicher Qualifikationen in Europa. Bielefeld: Bertelsmann, 40-60.

Esser, F. H. (2012). Die Umsetzung des Deutschen Qualifikationsrahmens. Hintergrund, Sachstand und anstehende Aufgaben. Berufsbildung in Wissenschaft und Praxis, 41(3), 47-51.

Euler, D., \& Severing, E. (2006). Flexible Ausbildungswege in der Berufsbildung. Nürnberg.

Fuller, A., \& Unwin, L. (2011). The Content of Apprenticeships. In T. Dolphin, \& T. Lanning (Eds.) Rethinking Apprenticeships. London: IPPR, 29-39.

Greinert, W.-D. (1988). Marktmodell - Schulmodell - duales System. Grundtypen formalisierter Berufsbildung. Die berufsbildende Schule, 40(3), 145-156.

Harris, R., \& Deissinger, T. (2003). Learning Cultures for Apprenticeships: a comparison of Germany and Australia. In J. Searle, I. Yashin-Shaw, \& D. Roebuck (Eds.) Enriching Learning Cultures. Proceedings of the IIth Annual International Conference on Post-compulsory Education and Training, Volume Two. Brisbane: Australian Academic Press, 23-33.

Harris, R. (2001). Training Reform in Australia - Implications of a Shift from a Supply to a Demanddriven VET System. In T. Deissinger (Ed.) Berufliche Bildung zwischen nationaler Tradition und globaler Entwicklung. Beiträge zur vergleichenden Berufsbildungsforschung. Baden-Baden: Nomos, 231-254.

Hogarth, T., Gambin, L., \& Hasluck, C. (2012). Apprenticeships in England: what next? Journal of Vocational Education and Training, 64(1), 41-55.

Jessup, G. (1991) Outcomes: NVQs and the Emerging Model of Education and Training: London: Falmer Press.

Keating, J. (2008). Qualifications Systems and National Qualifications Frameworks. Melbourne: Monash University.

Krewerth, A., \& Uirich, J. G. (2006). Wege und Schleifen zwischen dem Verlassen der Schule und dem Eintritt in die Berufsausbildung. In V. Eberhard, A., Krewerth, \& J. G. Ulrich (Eds.) Mangelware Lehrstelle. Zur aktuellen Lage der Ausbildungsplatzbewerber in Deutschland. Bielefeld: Bertelsmann, 69-82.

Kultusministerkonferenz (2007). Handreichungen für die Erarbeitung von Rahmenlehrplänen der Kultusministerkonferenz für den berufsbezogenen Unterricht in der Berufsschule und ihre Abstimmung mit den Ausbildungsordnungen des Bundes für anerkannte Ausbildungsberufe. Bonn: KMK.

Lorenz, K., Ebert, F., \& Krüger, M. (2005). Das neue Berufsbildungsgesetz - Chancen und Grenzen für die berufsbildenden Schulen in Deutschland. Wirtschaft und Erziehung, 57(5), 167-174.

Misko, J. (1999). Competency-based Training. Leabrook: NCVER.

Morgan, A. (1997). National Vocational Qualifications in a Business Studies Degree. Journal of Vocational Education and Training, 49(2), 181-195.

Neß, H. (2007). Generation abgeschoben. Warteschleifen und Endlosschleifen zwischen Bildung und Beschäftigung. Daten und Argumente zum Übergangssystem: Bielefeld: Bertelsmann. 
Ott, M., \& Deissinger, T. (2010). Frankreichs Berufsbildung im Spiegel der europäischen Berufsbildungspolitik: Eine komparative Analyse unter besonderer Berücksichtigung von Anpassungsproblemen und Anpassungsnotwendigkeiten. Zeitschrift für Berufs- und Wirtschaftspädagogik, I06(4), 491-516.

Prais, S. J. (1981). Vocational Qualifications of the Labour Force in Britain and Germany. National Institute Economic Review, 98 (November 1981), 47-59.

Raggatt, P. (1988). Quality Control in the Dual System of West Germany. Oxford Review of Education, 14(2), 163-186.

Ryan, P. (2001). Apprenticeship in Britain - Tradition and Innovation. In T. Deissinger (Ed.) Berufliche Bildung zwischen nationaler Tradition und globaler Entwicklung. Baden-Baden: Nomos, 133-157.

Unwin, L. (1999). Reforming the Work-based Route: Problems and Potential for Change. In A. Hodgson, \& K. Spours (Eds.) Dearing and Beyond: 14-19 Qualifications, Frameworks and Systems. London: Routledge, 75-87.

Weiss, R. (2007). Permeability: much remains to be done. Berufsbildung in Wissenschaft und Politik Special Edition 2007, 14-15 (http://www.bibb.de/de/29669.htm).

Westerhuis, A. (2011). The Meaning of Competence. In M. Brockmann, L. Clarke, \& C. Winch (Eds.) Knowledge, Skills and Competence in the European Labour Market. What's in a vocational qualification? London: Routledge, 68-84.

Winch, C., \& Hyland, T. (2007). A Guide to Vocational Education and Training. London: Continuum International.

Winch, C. (1998). Two Rival Conceptions of Vocational Education: Adam Smith and Friedrich List. Oxford Review of Education, 24, 365-378.

Winterton, J. (2009). Competence across Europe: highest common factor or lowest common denominator? Journal of European Industrial Training, 33(8/9), 681-700.

Wolf, A. (1998). Competence-Based Assessment. Does it shift the demarcation lines? In W.J. Nijhof, \& J.N. Streumer (Eds.) Key Qualifications in Work and Education. London: Kluwer, 207-219.

Young, M. (2003). National Qualifications Frameworks as a Global Phenomenon: a comparative perspective. Journal of Education and Work, 16(3), 223-237.

\section{AFFILIATION}

Thomas Deissinger

Department of Economics, University of Konstanz 